Estudios de la Paz y el Conflicto

Revista Latinoamericana

IUDPAS-UNAH

Volumen 1, Número 1, pp. 13-38

ISSN-e: 2707-8922 / ISSN: 2707-8914

DOI: $10.5377 /$ rlpc.v1i1.9514

Enero-junio 2020

\title{
JUST REKINDLE HOPE? SOCIAL AND POLITICAL IMPACTS OF THE 15M MOVEMENT IN SPAIN
}

\author{
¿SOLO REAVIVANDO LA ESPERANZA? IMPACTOS SOCIALES Y POLÍTICOS \\ DEL MOVIMIENTO 15M EN ESPAÑA
}

\author{
Miguel A. Martínez \\ Uppsala University \\ miguel.martinez@ibf.uu.se \\ Elena Domingo San Juan \\ Independent Researcher \\ dsjelena@googlemail.com
}

Cómo citar / citation

Martínez, M. y San Juan, E. (2020). "Just rekindle hope? Social and political impacts of the 15M movement in Spain", Estudios de la Paz y el Conflicto, Revista Latinoamericana,

Volumen 1, Número 1, 13-38. DOI: 10.5377/rlpc.v1i1.9514

\begin{abstract}
How to identify and assess the social and political impacts of a social movement such as the 15M/Indignados in Spain? A particular challenge comes up, first, when its limits and identity are blurred so here we distinguish three types of movement goals and explain how they emerged. Secondly, in order to evaluate their achievements we pay special attention to the usually neglected dimensions of movements' impacts - their self-reproduction, the non-institutional effects and the 'unintended consequences'. We argue that the $15 \mathrm{M}$ was able to challenge the authorities over the first three years of its existence by creating a counter-hegemonic political culture as well as a manifold set of practical initiatives of self-organisation. However, the institutional impacts were very limited, in spite of some significant successes and side-effects in the electoral arena. This is mainly explained by the resilient cohesion of the power elites and the continuation of the prevailing socioeconomic structures.
\end{abstract}

\section{Keywords}

Social movement's outcomes, self-reproduction, non-institutional effects, Spain, $15 \mathrm{M} /$ Indignados movement. 


\section{Resumen}

Cómo identificar y evaluar los impactos sociales y políticos de un movimiento social como el 15M/Indignados. El primer reto que se suscita es el relativo a los difusos límites e identidad del movimiento, por lo que en este trabajo distinguimos tres tipos de propósitos del movimiento y explicamos cómo emergieron. En segundo lugar, evaluamos los logros del movimiento de acuerdo a tres dimensiones insuficientemente analizadas por la literatura académica: la auto-reproducción del movimiento, los efectos no institucionales y las consecuencias no intencionadas. En este sentido argumentamos que el movimiento $15 \mathrm{M}$ fue capaz de retar a las autoridades durante sus primeros tres años de existencia por medio de la creación de una cultura política contra-hegemónica y una variedad de iniciativas prácticas de auto-organización. Sin embargo, los efectos institucionales fueron muy limitados a pesar de ciertos éxitos significativos y de los efectos indirectos en la contienda electoral. Estos procesos son explicados en función de la persistente cohesión de las élites de poder y la continuación de las estructuras socio-económicas dominantes.

\section{Palabras clave}

Impactos del movimiento social, auto-reproducción del movimiento social, efectos no institucionales, España, Movimiento 15M/Indignados.

\section{INTRODUCTION}

On May 15, 2011, a new social movement, the so-called 15M (due to that original date), ignited a storm of protest in Spain. It represented the first wide challenge to the ruling elites since the Transition, in the late 1970's, from a dictatorial regime to a democratic one (Espinoza, 2013; Rodríguez, 2013: 273). The 15M was also referred to as the Indignados (indignants, outraged) and the \#spanishrevolution. Before and after its appearance there were many episodes of unrest in other countries with some mutual connections and also many local singularities (Castells, 2012; Toret, et al. 2013; Flesher, 2014). Our main research question is: what were the social and political impacts of the $15 \mathrm{M}$ movement? The issue has been widely debated in the Spanish mass media, but there are not many scholarly contributions. First of all we present a critical review of the theoretical literature in order to identify the different dimensions of social movements' outcomes. Secondly we discuss the origins of the array of demands raised by the $15 \mathrm{M}$ so they can guide our assessment of success and failure. The next section is devoted to explaining which impacts were achieved and how relevant they were according to our interpretation of the development of the $15 \mathrm{M}$ over three years (2011-2014).

In this article we agree with other observers in considering that the $15 \mathrm{M}$ has been very successful in politicising and mobilising Spanish society in an unprecedented manner, although many of its explicit demands have not been met (Fernández-Savater, 2013a; Flesher, 2014: 176-177). In spite of the failures, the achievements would have implied, above all, the "rekindling of hope": "The criticism is focused on financial capitalism and on its influence on government, not on capitalism as such. The movement does not embrace ideologies of the past. Its quest aims at eradicating evil in the present, while reinventing community for the future. Its fundamental achievement has been to rekindle hope that another life is possible." (Castells, 2012: 197) According with this perspective the 15M showed a number of signs for a potential revolutionary change facing the capitalist system in Spain. It

Estudios de la Paz y el Conflicto, Revista Latinoamericana, IUDPAS-UNAH, Volumen 1, Número 1, enero-junio 2020, pp. 13-38. DOI: 10.5377/rlpc.v1i1.9514 
was predominantly an anti-crisis movement which reacted against the immediate effects of austerity and neoliberal policies implemented in the last term of the social-democratic government (López and Rodríguez, 2011; Stobart, 2014). This is not surprising given that a leftist inclination was evident among the 15M activists (Anduiza, et al, 2013) and the influence of autonomist, alter-global and cyber activists in the renovation of the political discourse beyond the traditional leftist clichés was also remarkable (Flesher, 2015). The novelty lay in the successful expansion of the 15M's demands to the broader public. In our view, the movement has also manifested direct opposition to the process of 'dedemocratisation' (Tilly, 2003) which involved continuing distrust of representative democracy and the way the political and economic elites abuse state institutions.

By the time of the European elections in May 2014, the discourse of hope was replaced by the discourse of the movement's decline and its transformation into new electoral coalitions and political parties. The latter received a sudden international attention due to their rapid growth -Podemos won five seats in the European Parliament just after three months of existence. According to our theoretical framework they may be properly conceived as 'unintended consequences' of the $15 \mathrm{M}$ given its non-partisan nature. However this eruption may overshadow the previous impacts of the $15 \mathrm{M}$ which are equally important, namely: 1) the $15 \mathrm{M}$ 's capacity to endure, mobilise and politicise due to a dense network of groups, coalitions, campaigns and calls to demonstrate which were active all over the period of three years; 2) the 15M was also able to materialise "hope" in the sphere of socio-economic and cultural changes since it catalysed, for example, the setup of multiple self-organised initiatives and new attitudes regarding civil disobedience (Fernández-Savater, 2013a; Gutiérrez, 2014; Bonet, 2015); 3) there were also some minor although significant impacts in the institutional realm of politics such as the lawsuit against a bailed out bank and the legal contestation of the privatisation of hospitals (Sánchez, 2013) that deserve to be highlighted (Romanos and Sádaba, 2015); 4) and we should point out to the diffusion of the 15M and its convergence with other social movements as well (Martínez and García, 2015).

As Giugni (1998: 374) suggests, we need to "specify the conditions that foster certain types of impact" and "to put movements and their outcomes in their larger social and political context". Therefore, this analysis contributes to the current debates on the consequences of social movements in two ways. First, we consider that the political potentialities of the $15 \mathrm{M}$ were closely related to the prevailing political arrangements (mainly institutional and stateoriented) in which the movement goals became meaningful and alluring for participants and supporters. Second, we verify that non-institutional impacts are more significant in the assessment of the $15 \mathrm{M}$ outcomes, which invites us to investigate those usually neglected scales and dimensions, especially for those movements which do not aspire to replace the state's sovereign power or take over the government (Viejo, 2007: 34; Holloway, 2002).

\section{DATA AND METHOD}

The empirical evidence for this study stems from a qualitative approach that has been implemented over four years, from 2011 to 2015. One of the authors conducted participant observation while being involved in the occupation of the Puerta del Sol (Madrid), numerous squatting actions, demonstrations, a working group and a local assembly. Informal interviews, email messages, documents and observational notes were collected in all these settings from May 2011 to July 2013, and over the month of June 2015. In addition, 24 semi-

Estudios de la Paz y el Conflicto, Revista Latinoamericana, IUDPAS-UNAH, Volumen 1, Número 1, enero-junio 2020, pp. 13-38. DOI: 10.5377/rlpc.v1i1.9514 
structured questionnaires with $15 \mathrm{M}$ activists were filled out up to January 2012 and 17 indepth interviews were held in June 2015. The second author conducted 15 in-depth interviews, June 2012. All these took place in Madrid although many other data were gathered directly and indirectly from other Spanish cities, and 10 more interviews and one focus group were also held with 15M Berlin activists who migrated to Germany after May 2011, between November 2014 and March 2015. The selection of the interviewees was done according to their involvement in different campaigns, movement organisations and actions related to the $15 \mathrm{M}$. The discourses and observations produced with the above techniques provided the activists' perspective that allows identifying the diversity of political goals, the assessment of their fulfilment and their relationship with their own trajectory within the $15 \mathrm{M}$ movement.

These discourses were analysed in combination with a continuous follow-up of the mass media coverage on the $15 \mathrm{M}$ up to the present, including the major Spanish newspapers, social networks, email lists, online publications (especially Madrid15M), activists' webpages and blogs. This complementary strategy enhanced the perspectives and information about the debates on the movement's outcomes. Regarding the online materials, instead of statistical content analysis we have implemented a specific form of virtual ethnography which consisted in three steps: 1) the identification of key meanings, expressions, opinions and events according to our research objectives; 2) the interpretation of their repetition and saturation by different authors and media so that we could establish a core of main ideas in order to nurture our argument; 3 ) the verification of their significance according to further practices, facts and objective evidences -both obtained from online and offline observations and conversations. In particular, the last round of interviews aimed at testing the initial hypotheses and discursive analyses.

\section{WHICH THEORETICAL DIMENSIONS FOR ANALYSING MOVEMENTS' IMPACTS?}

Research about social movement outcomes has been very controversial. On the one hand, the categories of 'success' and 'failure' depend on the researchers' interpretations as well as on the movement participants' and opponents' views. On the other hand, the available literature splits into different theoretical strands with their preferred variables and indicators to measure the movement outcomes. In this section we offer a brief critical review of the main contributions and argue that a thorough assessment of movement outcomes should take into account five main dimensions: (1) disrupting and challenging power, (2) power to change the institutional political process, (3) socio-economic and cultural changes, (4) impacts on other social movements and (5) unintended and contradictory consequences (see Figure 1).

Estudios de la Paz y el Conflicto, Revista Latinoamericana, IUDPAS-UNAH, Volumen 1, Número 1, enero-junio 2020, pp. 13-38. DOI: $10.5377 /$ rlpc.v1i1.9514 
Figure 1. Social and political impacts of movement's goals

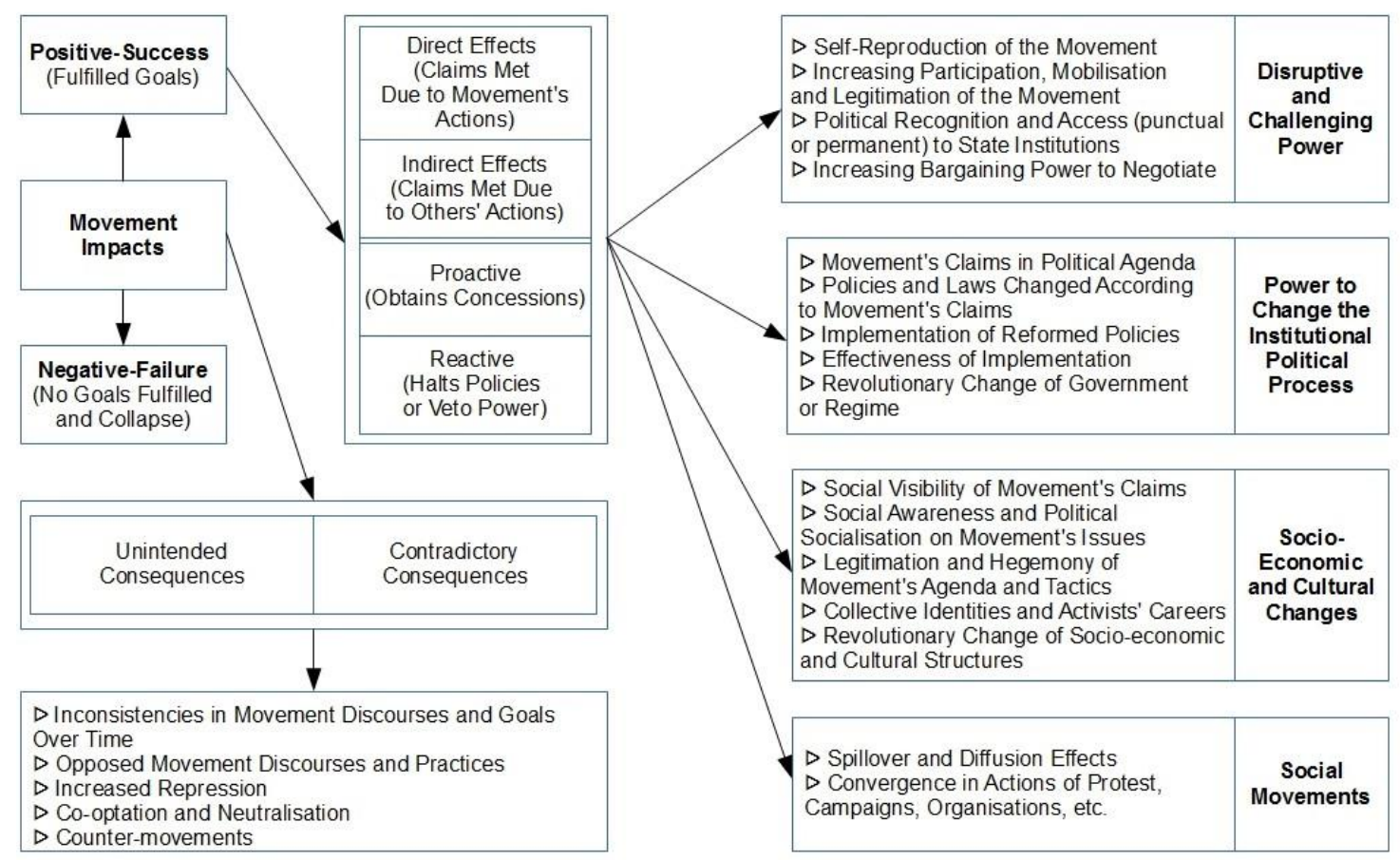

In essence, we arrived to this analytical scheme as a reaction to those voices who argued that the $15 \mathrm{M}$ was unable to achieve substantial impacts in the institutional sphere while dismissing the importance of other dimensions. Besides, we also felt unsatisfied with another prevailing analysis that focused almost exclusively or mainly on the cultural politicisation (or a "new political atmosphere") that the 15M would have been able to achieve. Our stance, then, is that we need to look at the whole picture of possible outcomes and to assess their significance according to the particular context in which the goals and development of the movement were contentiously defined (see Figure 2 for the main distinctions to consider in this contextual analysis).

For us, the most evident success of a movement is its continuation over time and making socially visible its claims to the surrounding society. The attraction of participants to its activities of organisation, protest and mobilisation and, not the least, the social support obtained and its reputation among bystanders may be seen also as positive outcomes. Thus, the persistent challenge to social forms of domination and inequality is one of the most immediate proofs of how some movements are able to reach political influence even without taking state power (Scott, 2012). Other impacts tend to occur after the initial forms of success are achieved and before the extinction of the movement. Concessions, co-optation and institutionalisation may contribute to that final fade out, although these phenomena are not necessary results of the movement evolution (Neidhart and Rucht, 1991). Concessions can fuel further demands, co-optation of some members or movement organisations might not erode the active core of the movement, and movements can give birth to 'anomalous social institutions' as practical means of survival (Martínez, 2014) while keeping alive their disruptive power of the status quo. 
Figure 2. Social and political context where movement's goals emerge and go visible

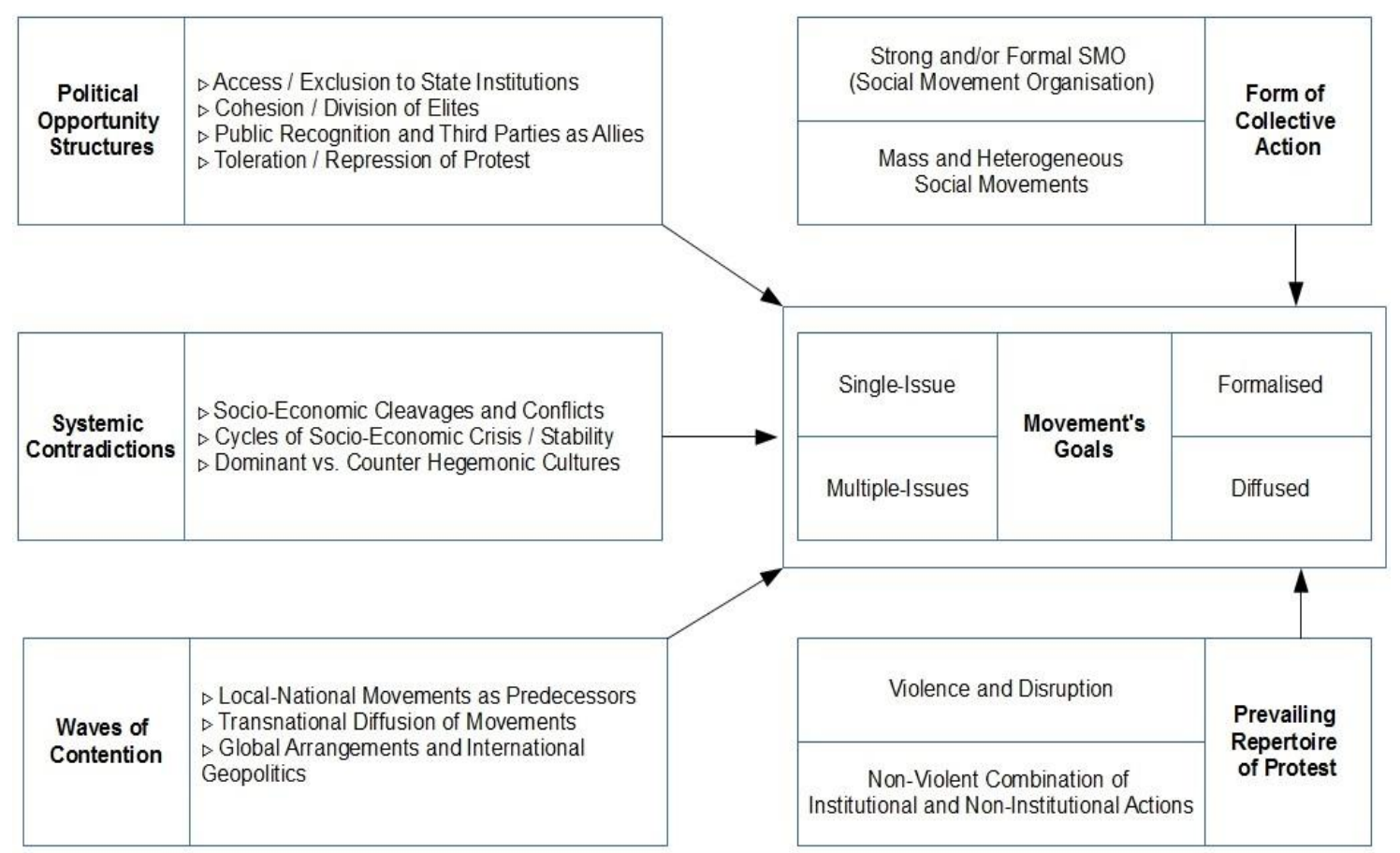

Apart from ignoring rule-breaking power (Piven and Cloward, 2005) as one relevant outcome, the mainstream literature lacks fruitful attempts towards integral perspectives (among the exceptions: Goodwin, et al, 2004). Sometimes the self-reproduction of the movement is neglected as a success because state-centred perspectives focus more or almost exclusively on policy changes and institutional effects. Other times the impact of movements in social identities and cultural values are presented at the same level of importance as repercussions in the political arena. Usually the significant contexts and the processes of interaction and evolution of the movement are not sufficiently specified and related to its demands. We see these three problems as limitations to be overcome if we aim at building an integral approach on movements' impacts.

Another conventional strand of research has stated that strong and cohesive organisations, as well as clear and single-issue goals, help movements to achieve success (Gamsom, 1990). This argument has often been challenged. For example, Piven and Cloward (1979: 5, 7, 14, 27-36) suggested that the context of "collective defiance" to political norms and to the ruling classes, including the class of the protesters, would explain better the outcomes of the movement. They convincingly argue that specific goals and demands are shaped along the process of social conflict expressed in collective action (ibid: 17). Therefore, we agree with them in pointing to systemic socio-economic contradictions as well as to political conflicts with the elites given specific opportunity structures, in order to understand how goals and hence outcomes are constituted.

Gamson also assumed that disruptive tactics and the use of violence contribute to the legitimation of protesters and to obtain advantages for those whom they represent (Gamson, 1990: 28-29). This has been disputed by claiming that, above all, specific events of violence should be clearly distinguished from durable challenges of social movements to powerholders (Giugni, 1998: 376-378). As we will see later, this is perfectly applicable to 
movements such as the $15 \mathrm{M}$ where prevailing civil disobedience was rarely contaminated with violent episodes while, at the same time, the movement gained wide legitimation and kept active its capacities to defy the elites over the years.

In our perspective then, goals, organisations and repertoires of protest arise within specific social and political contexts. This prevents us from taking them as isolated variables in order to explain the movement outcomes. The key dimensions specified by the focus on 'political opportunity structures' (Tarrow, 1994; McAdam, 1996; Kriesi, 2004; Meyer, 2004) form contextual structures where movements emerge, evolve and, consequently, impact as well. It is there where the claims are more or less formalised and where the different groups in conflict may argue that the goals are attained, or not. Although the access to state institutions and the role of elites are some of the most salient dimensions of this perspective, we endorse critics who include the activist interpretive agency and the cultural frames in terms of agenda setting, public opinion, collective identities and hegemonic discourses (McAdam, 1994; Giugni, 1998; Meyer, 2004). In addition, social class divisions and struggles, and the whole economic organisation and contradictions of a given society or territory, are the crucial material basis behind social uprisings and waves of protest, although it is very unlikely to observe their causal relationship with the wills of movements. According to McAdam (1994: 58-63) the more revolutionary the movement is in pursuing multiple goals of change, the greater the potential to engender cultural transformations in spite of its likely failure in the most ambitious political and economic aspirations.

Even in the cases where some social movements rise up as a direct reaction to certain policy decisions, the consequences of their actions may also go beyond the specific policy changes they aim to affect. In this regard we follow Tilly's (1999) distinctions between: a) 'direct success' of the movement that occurs when the claims are met due to its own actions; b) 'indirect success' of the movement when its claims are met due to others' actions and outside events; c) 'joint success' when the effects of the movement actions and the effects of outside events and actions overlap and the movement demands are satisfied; d) 'unintended consequences' in case of other movement and outsiders' actions produce impacts different to the most explicit movement claims. Burstein, et al, (1995) propose another useful classification. They define six types of 'policy responsiveness' that represent an increasing success as well as "greater resources at each succeeding stage" (Burstein, et al, 1995: 284): access (to achieve recognition or acceptance of the movement by the challenged authorities), agenda (to place movement demands in the political agenda), policy (to produce policies and legislation according to the movements claims), output (to implement effectively the policies desired by the movement), impact (to alleviate the grievances of the protesters by the actions of the political system) and structural (to transform the political structures and institutions). Letting aside the emphasis they put on the SMO (Social Movement Organisation) and formalised objectives, which are not common features of movements such as the $15 \mathrm{M}$, we also find crucial their focus on the interactions of movements, targets (political authorities or society at large) and the political context. Movement outcomes, thus, would depend on those interactions or power relationships, not simply on movement capacities, resources and identities (see also Kriesi, 2004).

Burstein et al.'s proposal may be enlarged by adding more 'scales' or dimensions to the less institutional stages of their model -access and agenda. In our view, the capacity of the movement to recruit, self-organise and mobilise, needs to be regarded as a distinctive contribution to nurture the political arena at large (Fuchs, 2006; Calle, 2007). While the notion of 'scales' may help to decide among different degrees of satisfaction of the claims,

Estudios de la Paz y el Conflicto, Revista Latinoamericana, IUDPAS-UNAH, Volumen 1, Número 1, enero-junio 2020, pp. 13-38. DOI: $10.5377 /$ rlpc.v1i1.9514 
the presupposition of a continuous escalation of movement outcomes relies on an external rationality that can easily neglect their mutual overlapping. Burstein et al.'s concepts shed light on the institutional effects, but they cover only one part of the picture. For example, movements may try to address, above all, public attention and raise social awareness about issues formerly considered private, such as gender violence, discrimination against women, homophobia or racism. Furthermore, movements can have impacts on other movements such as spillover effects (Meyer and Whittier, 1994) and transnational diffusion (Tarrow, 2005) or indeed converge with each other (Martínez and García, 2015). As Koopmans (2004: 25) noted, both diffusion processes and political opportunities can be also found in the original context of a movement, as a part of a 'wave of contention', usually crossing national boundaries. Regarding undesired consequences, a classic example is the emergence of counter-movements, such as conservative ones which opposed feminist claims about abortion rights, gay and lesbian families, and sex education (Whittier, 2004).

\section{HOW DO THE MULTIPLE 15M MOVEMENT'S GOALS EMERGE?}

In March 2014, almost three years after the 15M exploded, the discourse that frames the current political initiatives of mobilisation remained tightly close to what was expressed in the first months after May, 15, 2011. For instance, the most repeated slogans displayed in the Marchas por la Dignidad (Marches for Dignity, different columns of demonstrators reaching the city of Madrid on March 22, 2014, after walking several weeks from different corners of the country, as a replication of a similar action which took place in July 2011) were: against unemployment and precarious work, claiming for more jobs and decent working conditions; against cuts and privatisation of public services, claiming universal access to (and defence of) the Welfare state; against foreclosures and unaffordable housing, demanding effective rights to decent housing; against corruption and the "illegitimate debt", in favour of getting rid of the rule of the major political parties and of changing the basic consensus underlying the institutional structure of the Spanish and European representative democracy (SR, 2014). The high turnout of participants in these demonstrations showed how alive the $15 \mathrm{M}$ was. Other groups were still adding more substantive or particular claims (DRY, 2014; MPD, 2014).

Going back to May 2011, the various thematic working groups and regular assemblies that formed the most active core of the occupied squares at that time, produced hundreds of similar demands (Pastor, 2011: 111). Amongst all the slogans displayed at the Puerta del Sol two kinds prevailed: criticisms of the representative democracy and the bi-party dominance of the institutional system ("PP and PSOE do not represent us"); a deep discontent for the economic crisis with its consequences of unemployment, poverty, precariousness, privatisations and cuts on social welfare ("we won't pay for this crisis" and "this crisis is a fraud") (Adell, 2011: 162). Although continuous demonstrations and direct actions, in addition to a vibrant internal dynamics of self-organisation, occurred, only in few occasions were there attempts to make explicit claims in the form of a short political programme (an exception: DRY, 2012). The so called "spirit of the 15M" pervaded most of the mobilisations between 2011 and 2014. This was due to the implicit and diverse set of claims as well as to its appealing organisational style -horizontal assemblies, inclusiveness, autonomy from formal organisations, prevailing civil disobedience in combination with some institutional actions, etc. (See our classification of specific contents in Figure 3)

Estudios de la Paz y el Conflicto, Revista Latinoamericana, IUDPAS-UNAH, Volumen 1, Número 1, enero-junio 2020, pp. 13-38. DOI: 10.5377/rlpc.v1i1.9514 
The above has evident implications:

a) There were always (between 2011 and 2014) 'explicit claims' raised by the $15 \mathrm{M}$ movement.

b) There was also a diverse range of varied and specific claims that were not so visible to public opinion, the media or other participants in the movement ('diffuse claims').

c) There were many groups, organisations and ways of expressing the demands -so that the "specific organisations' claims" supplemented the general critical discourse of the $15 \mathrm{M}$.

d) Sometimes the most overt claims were formalised as short programmes but there was no consensus about them between all the branches of the movement.

e) There were claims pointing to radical reforms and revolutionary changes, although most called for immediate actions to halt the consequences of the economic crisis and its political governance.

\section{Figure 3. Claims raised by the $15 \mathrm{M}$ Movement}

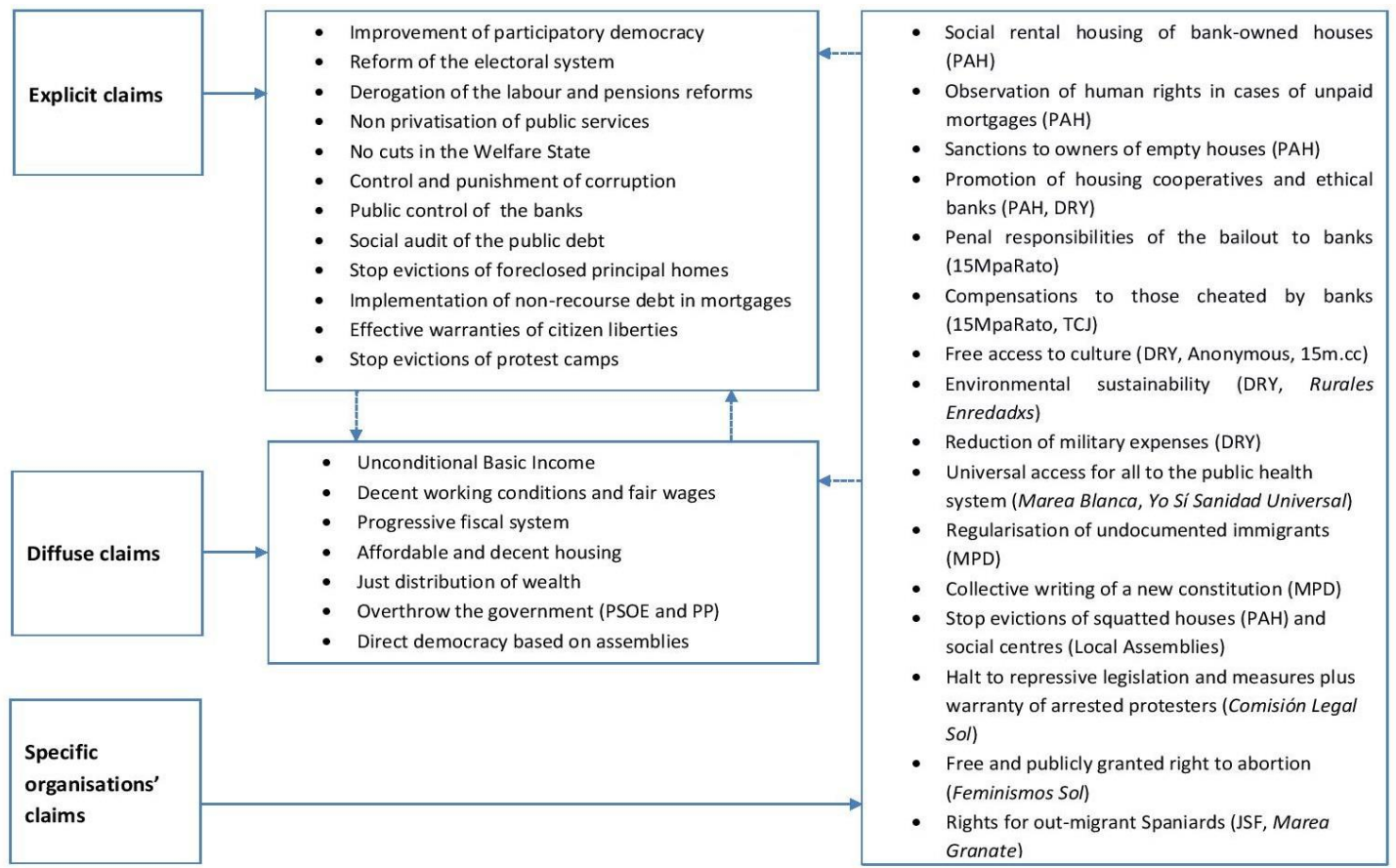

The $15 \mathrm{M}$ is thus the general umbrella used to name the hope in revolutionary change for some and of urgent radical reforms for most. Neither one nor the other were ready-made political programmes. This suggests that any analysis of the impacts produced by the $15 \mathrm{M}$ should consider the broad number of claims in the three mentioned domains -'explicit', 'diffuse' and "specific organisations' claims" In addition, the 15M participants formalised demands within the particular structural opportunities and constraints of significant contexts where the movement emerged. Historically, the $15 \mathrm{M}$ sparked a new political cycle of mobilisations in which many lessons regarding skills, communicative resources and repertoires of civil disobedience were learned from the previous one where anti-war campaigns, students' protests, housing struggles and others took place (Flesher, 2011; OM, 
2011: 73-75; Romanos, 2013: 209; Toret, et al, 2013; Martínez and García, 2015). Thus the anti-austerity claims of the $15 \mathrm{M}$ were rooted in previous local and transnational movements, mobilisations and protest campaigns. These created discursive frames which still resonated as valid claims in 2011. To a certain extent, the 15M activists selected their political goals among the sources provided by preceding movements. In addition, the 2008 financial crisis provoked an immediate social and transnational unrest (OM, 2011; Flesher, 2014) which was somehow inspirational as was illustrated in the banners and debates held by the $15 \mathrm{M}$ activists according to our own in situ and online observations. Therefore, the multiple claims displayed by the $15 \mathrm{M}$ activists had more chances of resonating nationally and transnationally -although the contexts and particular claims differed.

More importantly, as Stobart (2014) has noted, in the spring of 2010 the social-democrat government of the PSOE made a substantial shift under the pressure of the European Union, the US and other international institutions. Cuts in public sector wages were implemented. Reforms of the labour legislation and the retirement age justified a general strike in the fall of that year. Other neoliberal and austerity policies were intended to satisfy creditor interests. Unemployment rate soared beyond 22\% at the end of 2011. Privatisations were also the flagship issue of the other major political party, the conservative PP, in the regions and municipalities where they were in office. Trade unions were fragmented and weak. Between 2008 and 2011 hundreds of cases of corrupt politicians were shown in the mass media to have colluded with the companies behind the construction boom of the past decade. The huge stock of vacant houses (approx. 15\%) and the difficulties in gaining access to affordable housing for a large number of underpaid workers supplemented the grievances (López and Rodríguez, 2011). At the same time, the few progressive social policies put forward by the PSOE suffered continuous attacks by religious and right-wing mobilisations in the streets that overshadowed other protests due to the biased coverage of the conservative mass media. The $15 \mathrm{M}$ reacted against this context; it was not only a mechanical response to the economic crisis. In particular, their most immediate target was the government of the PSOE in order to disobey austerity measures and to maintain a basic welfare state.

The demand for a deeper and stronger democracy coincided with increasing poverty, the elimination of public services and subsidies and, in short, the erosion of middle class and working class incomes. This reinforced notions of equality and social rights within the concept of 'true democracy', which were not usual in the previous years of economic growth. For many, then, a new foundation of the pillars of democracy, or a new constitution, was needed. Moreover, a decline in the usefulness of representative democracy, as a symptom of the ongoing process of de-democratisation, was perceived as a general threat that added to the whole set of grievances. Thus, those involved in the $15 \mathrm{M}$ chose strategically its preferred goals according to the most salient tensions and conditions of the political context. These goals gained social recognition due to five specific genealogical conditions and mechanisms:

1) The consensus reached among the organisations united in DRY (Romanos, 2013; Abellán, 2015).

2) The international coverage of the municipal and regional elections of May 22, 2011 which facilitated the presence of 15M in worldwide news (Adell, 2011).

3) The catalysing effect of the protest camp at Puerta del Sol square in Madrid which provided a long-lasting platform of political demands beyond the elections.

4) The interaction of the $15 \mathrm{M}$ with the initially slow to repress authorities increased the visibility of the multiple movement goals.

Estudios de la Paz y el Conflicto, Revista Latinoamericana, IUDPAS-UNAH, Volumen 1, Número 1, enero-junio 2020, pp. 13-38. DOI: 10.5377/rlpc.v1i1.9514 
5) The general elections won in November 2011 by the PP, also reinforced the focus on the shortcomings of representative democracy and two-party machinery.

\section{DIMENSIONS OF THE 15M MOVEMENT'S IMPACTS}

As a consequence of our understanding of the types of goals and the context from which they emerge, the question concerning whether the $15 \mathrm{M}$ movement succeeded or failed entails a process-like approach. Although the multiple goals of the movement did not change substantially over three years, they have been claimed in different ways and under different circumstances by different groups. Accordingly, we argue that the final impacts would result from the specific contexts of power relationships in which those and other social groups were involved over time. This seldom takes the form of a functional relationship between means and ends.

\section{The continuing effects of the movement's self-reproduction}

The $15 \mathrm{M}$ evolved as an array of multiple groups, protest events and campaigns. Some of these manifestations overlapped and some lasted longer than others but all involved core groups of activists and supporters at various levels. Some activists jumped from one group or event to another, while others simply quit at a certain point ${ }^{1}$. Without any single SMO leading the movement, politicians, journalists and academics usually referred to the $15 \mathrm{M}$ movement as something more or less vague. However, there is a general consensus amongst all groups that the $15 \mathrm{M}$ has modified the political life in Spain since its inception.

"When we organized the first demonstration on the 15th of May, we didn't know that this movement was going to be like this. We thought it was going to be a normal demonstration. (...) But when we went to that demonstration and we saw people occupying the squares in Madrid and the next day we had so many people there in Seville, we realised on the very first day that this was not a normal movement and something strange was happening there. (...) So it was not normal that we get not only a demonstration and an occupation of the square but also mass assemblies every night." (Interview with M1, male, 34, Spanish migrant in Berlin, 2014)

"I believe that the cycle opened by the 15M has been the best thing that happened to us. I do not consider it just a mobilisation cycle but a cycle of collective political learning. We came from a country with a very weak civil society that suddenly awakened. People started talking about external debt, the real-estate bubble, the stock of public rental housing, the value of public health and education, our declining labour rights, etc. It seemed that the more we lost, the more we valued it and the more we strived for it. The Marches for Dignity (in 2014 and 2015) were something never seen before -more than one million people without the support of neither the PSOE nor the main labour unions. And there was also an absolute media censorship and road controls (by the police). It seemed that the 1978 Regime was inevitably collapsing." (Interview with E, male, 39, Spanish visiting university professor in Chile, 2015)

\footnotetext{
${ }^{1}$ As for April 2014, more than 100 cases of groups and campaigns could be associated to the $15 \mathrm{M}$ (www.autoconsulta.org).
}

Estudios de la Paz y el Conflicto, Revista Latinoamericana, IUDPAS-UNAH, Volumen 1, Número 1, enero-junio 2020, pp. 13-38. DOI: $10.5377 /$ rlpc.v1i1.9514 
We argue that one of the reasons for such a consideration is that the movement has shown an extraordinary capacity to self-reproduce as no other movement did before in the Spanish context since the protests at the peak moments of the late 1970s. The 15M was also able to incorporate many different struggles under a common set of meanings and practices. Furthermore, every new form of participation may be seen as an impact of the pioneering ones. The development of single initiatives or campaigns combined or simplified some of the $15 \mathrm{M}$ goals into concrete contexts. As a consequence, given this specific evolution, the success or the failure of the $15 \mathrm{M}$ not only depends on the general goals of the movement at large but also on the impacts of its reproduction at different stages.

\section{Access to state institutions and bargaining power}

The success of the $15 \mathrm{M}$ regarding the access to state institutions and the production of bargaining power was hardly met with the exception of some specific groups. When successful, the goals were fulfilled in close relation to a number of issues that the $15 \mathrm{M}$ was able to incorporate into the political agenda:

1) In particular, it was the PAH the most salient and effective organisation in doing so given their involvement in negotiations with municipal governments, the legal aid they offered to evicted people and, above all, the Citizen Initiated Legislation that they launched and which obtained 1.5 million of signatures -although it was finally rejected in the Parliament. The PAH is not a pure 15M group (it was born in 2009), but a housing movement based on a strong SMO and narrowly-defined demands. However, its convergence with the $15 \mathrm{M}$ was intense and fruitful ever since its first participation in the coalition with DRY (Colau and Alemany, 2012; Delclós, 2013; Abellán, 2014).

2) Secondly many local groups and assemblies of the $15 \mathrm{M}$ actively participated in the municipal councils and deliberations, although their access to these institutions was usually very unstable (see many cases in the activist publication Madrid $15 \mathrm{M}$ such as 2012b and 2012c; and also the still active group Graba Tu Pleno which encourages activists to video record every municipal plenum).

3) A third example of this impact was the campaign "15MpaRato" which consisted of launching a penal lawsuit, backed by crowdfunding, against the managers and political authorities responsible for the activities of one of the major banks bailed out by the state, Bankia (15MpaRato 2014).

4) The so called "white tide" (Marea Blanca) within the public health system was also very successful with their legal opposition to the privatisation of hospitals in Madrid, and the highest regional authority (Secretary of Health) stepped down once his plan was defeated in court (Sánchez, 2013). Many institutional and non-institutional protests against the cuts and the privatisation of hospitals were also eventually effective in Catalonia due to the cooperation between 15M activists and other groups and political parties with municipal representation (Grup de Defensa, 2015; Díaz and Ubasart, 2012).

5) Regarding the occupation of buildings, one of the $15 \mathrm{M}$ local assemblies in Madrid (Montamarta) was able to negotiate and be granted the right to use one old city-owned market even after the sudden eviction of the squatters (Martínez and García, 2015; Montamarta, 2015). Other squats for housing purposes were also empowered to

Estudios de la Paz y el Conflicto, Revista Latinoamericana, IUDPAS-UNAH, Volumen 1, Número 1, enero-junio 2020, pp. 13-38. DOI: $10.5377 /$ rlpc.v1i1.9514 
negotiate with the authorities and to reach practical agreements or provision of affordable public housing (especially those promoted by the PAH and the so called corralas in Seville: Stelfox, 2013; Corrala, 2015).

Nonetheless, the $15 \mathrm{M}$ was ineffective in changing the core of institutional politics over the first three years. Furthermore, neoliberal, regressive and more authoritarian policies were enacted (for example, the new repressive measures: Amnesty International, 2014) which contributed to the unintended consequences of the 15M. However, instead of a definite knock out of the movement, every time new faces and protest actions emerged. The movement failed but did not give up speaking out. This persistence made it possible to have a say in the political agenda in both direct and subtle manners until the emergence of Podemos political party and similar electoral candidacies at the municipal and regional levels after 2014.

In addition, the 15M contributed to the erosion of votes for the two major parties (PP and PSOE), to improving the results of other minor political parties (IU, UPyD, ANOVA and CUP), and to slightly increasing the percentage of non-valid and blank votes, as well as abstention from voting (Anduiza, et al, 2013). On November 20, 2011, the general elections ended with the victory of the conservative PP which openly declared to bring forward new labour reforms and to reduce state spending. Initially, most of the participants in the $15 \mathrm{M}$ never absolutely opposed the elections. However, most activists endorsed measures to improve more participatory, direct and on-line mechanisms of democracy. These favoured options, in practice, did not prevent activists and sympathisers from voting, but, quite the opposite, encouraged them to vote and to punish the two-party (plus CIU) hegemony (Pastor, 2011; Adell, 2011). Thus, the 15M forced most of the political parties to include some of its more moderate demands in their electoral programmes, such as the reform of the electoral system, the regulation of citizen initiated legislation, administrative transparency, a stricter punishment of corruption, the creation of public banks and the bill to enforce the nonrecourse debt for unpaid mortgages (Calvo, 2011; Gálvez, 2011). The 15M affected the electoral strategies without even a single vis-à-vis negotiation with the political parties until the eruption of the new ones in 2014 and 2015 where former 15M activists became key members. Thus the movement obtained a partial -and partially unintended- success, still far away from its broader goals.

The 15M had no partisan affiliation either and most of the groups and organisations did not gain direct access to state institutions. However, many left wing political parties (IU, Equo, Compromís, CUP, ANOVA, etc.) tried to persuade the 15M activists that they could represent them faithfully. As argued, the support of the $15 \mathrm{M}$ to these parties was implicit and merely tactical, in order to undermine the power of the dominant ones. In January 2013 a new political party called "Red Ciudadana Partido X" aimed to give an institutional and stable continuity to the core claims expressed by the $15 \mathrm{M}$. It focused mainly on electronic devices to improve democratic participation and the struggle against corruption -and some of their members also launched the campaign 15MpaRato. Another surprise and the most outstanding example of the hopes engendered by the $15 \mathrm{M}$, was Podemos. This political party was born in February 2014 only as a joint initiative of a far-left political party (Izquierda Anticapitalista) and several intellectuals and activists. Their basic political programme and its decentralised organisation mirrored the 15M's claims and structure. Overwhelming initial expectations, Podemos obtained more than 1.2 million votes and 5 elected members in the European Parliament. In the regional elections of Andalusia, in March 2015, they won 15\% of the votes and 15 seats.

Estudios de la Paz y el Conflicto, Revista Latinoamericana, IUDPAS-UNAH, Volumen 1, Número 1, enero-junio 2020, pp. 13-38. DOI: $10.5377 /$ rlpc.v1i1.9514 
Both initiatives, Partido $X$ and Podemos, were somehow contradictory. They could neither substitute for the $15 \mathrm{M}$ nor claim its direct representation. The partisan autonomy of the $15 \mathrm{M}$ contributed to its credibility and legitimacy. Members of the new political parties intended to have a say within the state institutions by arguing that the $15 \mathrm{M}$ was not capable of doing so itself. However, both declared their aspiration to be 'institutional interfaces' in order to help the $15 \mathrm{M}$ expand its institutional impact. Thus, they can be conceived as both unintended outcomes and strategic allies who contributed to maintain the $15 \mathrm{M}$ challenge to power even as it declined:

"Yesterday Podemos' militants were able to fill the main plaza of the neighbourhood, in the same place where the Popular Assembly started to work three years ago. Over these three years we have ended up in a small group of 30 after being hundreds in the beginning. People think that by attending one or two assemblies they will change the world. Once they see this does not happen, they get frustrated and go back to their apathy. Obviously, for the neighbours the assemblies were inefficient and now they see Podemos as a tool to bring the struggle and the change into the institutions." (Facebook post by JF, male, 15M activist, 26 September, 2014)

The $15 \mathrm{M}$ has also tried to influence institutions by using alternative means. Among the most relevant ones were two public consultations against the privatisation of the water supply and six hospitals in Madrid (Sánchez, 2013). Both were very successful in terms of signatures collected (165,000 and 1,082,300 votes, respectively) and they also combined with other institutional (legal trials, meetings with political representatives, participation in municipal plenums, etc.) and non-institutional initiatives (demonstrations, sit-ins in public roads, human chains around hospitals, organised disobedience to facilitate health services to undocumented migrants, etc.).

Other organisational interfaces or attempts to establish 'movement institutions' were less ambitious, but added diversity and developed issues that arose in the squares (for example, Comision Legal Sol with the provision of legal aid and reports on state repression, Oficina Precaria with a critical focus on the precariousness of work and support to workers' struggles, and the Tribunal Ciudadano de Justicia 15-M aiming to research on the legal responsibilities of banks).

In general, the capacity of the $15 \mathrm{M}$ to affect the institutional process was low and poor if compared to the ambitious challenges that the movement produced over three years. However, in spite of this overall assessment, the above mentioned efforts and achievements in the institutional sphere are sufficient evidence to show that the $15 \mathrm{M}$ movement was not a pure institutional outsider or an utopian counterpower in parallel to the state. The attempts to access the state sites of power and some victories in that arena entailed significant institutional impacts that, in addition, paved the way for the articulation of new political parties in which many $15 \mathrm{M}$ activists and supporters reshaped their hope.

\section{Impacts on social, cultural and economic dimensions}

Our following evaluation of the outcomes produced by $15 \mathrm{M}$ points to its outstanding success in accordance to the movement's main aspirations -that is to say, the impacts on the noninstitutional dimensions. The $15 \mathrm{M}$ created a meaningful response to the crisis and the neoliberal policies that transcended traditional left and right wing political alignments. In doing so, it was able to break the cultural hegemony that prompted people on consumerism, 
preserved politics as an exclusive field for professional politicians and experts, and censored or dismissed radical protests. The $15 \mathrm{M}$ also brought together different social movements and social groups to unite in a common cause. In practice, this gave birth to a stream of strong public deliberation that politicised many aspects of daily life. Politics was no longer the sole realm of state institutions and political parties. Even the labour strikes gained more social engagement than ever before, despite the low rate of union affiliation. As highlighted by early research based on surveys and focus groups, the strategic goals of the $15 \mathrm{M}$ movement and its tactical protests won general sympathy and legitimation (INJUVE, 2011a; Campo, 2012). This shaped a distinctly non-institutional and autonomous ground of politics that was largely disconnected from the arena of electoral participation and preferences in the first three years of its development.

Civil disobedience, for example, never before was so widely practised and justified -unlicensed camps and demonstrations, human barriers to oppose forced evictions by police and judicial authorities, illegal squatting of abandoned buildings, etc. In comparison to the main historic precedent in Spain, the successful and long lasting campaign against the conscription for military service between 1988 and 1996 (MOC, 2002), the social scope of activists and the number of workshops organised by the $15 \mathrm{M}$ groups to promote peaceful civil disobedience was much wider (see, for instance: Comisión Análisis, 2011; 15M Horta Albufera, 2011; 15M Escorial, 2012; Derechos civiles 15M Zaragoza, 2014).

Moreover, a day-to-day politics was embraced in terms of specific practices where the $15 \mathrm{M}$ discourses were pervasively produced, circulated, used and fed back. The most wellknown landmark in this learning process of politicisation is the widespread practice of assemblies, horizontality and direct democratic mechanisms which, again, was never before developed in such large scope by the preceding autonomists movements in Spain (Cabezas, 2011; Nez, 2012; Corsín and Estalella, 2013; Moreno, 2013). The wide array of selforganised projects that proliferated from the core groups of the $15 \mathrm{M}$ or in close association with them had their major reference in the "housing movement" ignited by the PAH. This was then able to establish strong and completely novel networks of solidarity between people threatened by evictions and activists with many different backgrounds, linked to migrants' associations, neighbourhood activism, political parties, squatters, students, lawyers, accountants, psychologists, etc. (Colau and Alemany, 2014; Romanos, 2014). In Madrid, for example, many $15 \mathrm{M}$ local assemblies and activist groups working on housing issues started to cooperate and campaign together from 2011 onwards -a collaborative step which was not possible in the previous Movement for a Decent Housing between 2006 and 2010 (Aguilar and Fernández, 2010; Blanco, 2011). The occupation of buildings for housing purposes or as social centres became, thus, a key illustration of these new alliances. The number of squats and the public acceptance of squatting as a legitimised non-institutional action of protest also became a milestone of the multiple forms of self-organisation which emerged out of the $15 \mathrm{M}$ movement (Martínez and García, 2015). The extension of squatting after the 15M is explicitly and cheerfully recognised by most of our interviewees:

"The squatters' movement contributed to the 15M's structure (...) by avoiding vicious manipulations in the key assemblies, by trying to decentralise the structure of power, always backing arrested people and being very cautious about mass media." (Interview with $\mathrm{O}$, female, 30, Spanish activist in the squatter and queer movements in Madrid, 2011)

"We saw how the messages we (squatters) tried to spread throughout the years without any success, such as self-organisation and disobedience, suddenly reached all kinds of people who did

Estudios de la Paz y el Conflicto, Revista Latinoamericana, IUDPAS-UNAH, Volumen 1, Número 1, enero-junio 2020, pp. 13-38. DOI: $10.5377 /$ rlpc.v1i1.9514 
not fit the profile of revolutionary militant we were used to." (Interview with $\mathrm{H}$, male, 28, Spanish activist in squatting and independent media, Madrid, 2011)

"Concerning squatting, I believe that the 15M has achieved what we (squatters and autonomists) were not able to do during several decades: to turn squatting into a natural discourse and repertoire, as a valid alternative for broader audiences without scandalous prejudices which were so frequent before. Nowadays there are many more people involved in these processes (of squatting) who never would have approached a squatted social centre before. Now squatting is seen (by $15 \mathrm{M}$ and $\mathrm{PAH}$ activists) as a temporary residential alternative and as a response to the housing question and the eviction of people from their homes. This is an enormous qualitative shift. (...) Squatting has been more de-criminalised. (...) The (squatted) Hotel (next to Puerta del Sol) has achieved that lots of people walk in a social centre and participate naturally in assemblies. The myth of the squatter has been vanished." (Interview with S, female, 32, Spanish activist in squatting and the 15M Legal Committee in Madrid, 2011)

Some working groups, such as Economía Sol or La Uni en la Calle, were like regular outdoor schools while combining collective and accessible production of knowledge with overt political claims. Similar on-line developments were the open-source wikiencyclopaedia 15 m.cc and the collaborative library Bookcamping. Closely connected to the $15 \mathrm{~m}$.cc project was also one of the multiple documentaries produced about the $15 \mathrm{M}$ and its intentions attempting to expand its social and political influence (15mm.cc, 2015). These $15 \mathrm{M}$ groups, then, changed the access to information and knowledge for activists, sympathisers and bystanders at the same time questioning more formal educational institutions and the austerity policies they were experiencing. This impact is also imbricated with the self-reflexivity and self-reproduction of the movement since is mainly carried on by some of the various groups identified with or belonging to the decentralised network of the $15 \mathrm{M}$.

Beyond the $15 \mathrm{M}$ groups and focusing on more material basis, new working co-operatives started up and all kinds of social economy initiatives (such as ethical banks) received much more attention than ever before because belief in the 'free market' lost ground (Elola, 2012; Oliden, et al, 2013). Not only many of our interviewees and those quoted by the news collected declared their involvement in ongoing co-operative projects (both legal and informal ones), but also the overall number of these economic initiatives experienced a specific economic behaviour compared to other businesses after 2011. In particular, the number of cooperative companies had also grew up in the Transition period in the aftermath of the Dictatorship (1975) but it reached a peak in 1995, just when the economic boom, the real estate bubble and intense immigration flows changed the country's economic profile (Díaz and Marcuello, 2014). It was in 2008 with the Global Financial Crisis that the number of cooperative companies halted its continuous decline in number since 1995 and it has been argued that social and democratic economies survive better periods of crisis (Sala, et al, 2014; see also the updated records by the Ministerio de Empleo, 2015). In a similar vein to the rise of stealth squatting for housing beyond the public actions of the PAH and the local assemblies, the influence of the $15 \mathrm{M}$ on the cooperative economy is not easily traceable in quantitative terms - related experiences such as the so-called "food banks" launched by $15 \mathrm{M}$ activists should be considered part of the same broad category. What this means, according to all the personal declarations and indicators we gathered in news and $15 \mathrm{M}$ publications, is that there was a strong association between cooperatives and the deep transformations called for by the $15 \mathrm{M}$. This discourse has served to inspire $15 \mathrm{M}$ activists and others in order to create cooperative companies. A few examples of these outcomes:

Estudios de la Paz y el Conflicto, Revista Latinoamericana, IUDPAS-UNAH, Volumen 1, Número 1, enero-junio 2020, pp. 13-38. DOI: 10.5377/rlpc.v1i1.9514 
"I am currently working at home but also seeking the way to self-employ me with a friend in a cooperative." (Interview with M, female, 29, Spanish activist in a squat in Madrid, 2011)

In the on-line survey applied in 2013 where 4,304 people responded, "consumption cooperatives; workers' cooperatives of journalists, architects and graphic design; cooperatives in the Market of San Fernando (Madrid); barter groups and time banks" were among the many "collectives, movements and actions associated with or belonging to the 15M" movement (Llámalo Y, 2013; La Huerta del Sol 2015 declares explicitly that was born "in the heat of the $15 \mathrm{M}$ as an initiative of the Assembly of Unemployed People in Puerta del Sol").

The independent social network N-1 where many $15 \mathrm{M}$ groups developed their initial and intense communications had 364 members in the area of "promotion of cooperatives" which represented the third most populous one by August 2011 (Toret, et al, 2013: 397).

Members of the pioneering Cooperativa Integral Catalana (which was created before 2011) attended numerous debates and meetings with $15 \mathrm{M}$ groups aiming to support the creation of similar projects (see, for instance, Asamblea de Logroño, 2013).

On October 2011, Michael Albert, one of the proponents of Participatory Economics, gave a talk in the local assembly of Lavapiés where some months later some of the activists set up a non-legally constituted food cooperative to support immigrants (from our own participatory observation, see also ZNet, 2015).

\section{Impacts on other social movements and the mobilisation cycle}

One final illustration of the $15 \mathrm{M}$ outcomes refers to the changes in the social movements' milieu. The most striking aspect of its evolution is the extension of broader movement coalitions. The Green Tide (Marea Verde) and the White Tide (Marea Blanca), for instance, incorporated in their struggles not only workers in the public services, but also professional and labour unions, users of all ages and a number of supportive groups that made collective actions very hybrid, horizontal and cooperative -for the first time ever in these fields in Spain

(Sánchez, 2013). The 15M sparked and strongly supported these and other tides while avoiding any organic integration or formal coordination. The two general strikes that took place in March and November 2012 gained a higher turnout in the demonstrations and direct actions compared to the preceding ones (2010, 2003 and 2002). Many 15M groups called for joining the strikes and these mobilisations depicted the dawn of stronger ties between both movements (the $15 \mathrm{M}$ as a broad anti-austerity, anti-corruption and anti-de-democratisation movement, and the workers' one) (see, for example, 15M Málaga, 2012; Madrid15M, 2012a; and Carmen y Carlos, 2015). Two recent cases where that cooperation and convergence overtly occurred were the following: a) the Marches for Dignity (in March 2014 and 2015) showed new instances of 'united fronts' and transversal politics in which no single classic leftist identity or flag occupied the foreground and the final stage as a dominant one, except in the headlines of the right-wing newspapers (Alvarez, 2014: b) the demonstrations against the TTIP (Transatlantic Trade and Investment Partnership) between the European Union and the United States verify how this coalition is still going on in April 2015 (Diso Press, 2015).

As it is barely mentioned in Figure 4, we might include in this box the diffusion of the

$15 \mathrm{M}$ to other Occupy-like movements (which entails some direct links but also many significant differences: Fernández-Savater, 2013b; Flesher, 2014) and the convergence with 
other movements such as the feminist, the pacifist, the squatters and the free culture (Morell, 2012; Toret, et al, 2013; Cruells and Ruiz, 2014; Martínez and García, 2015).

\section{Figure 4. Social and Political Impacts of the 15M Movement}

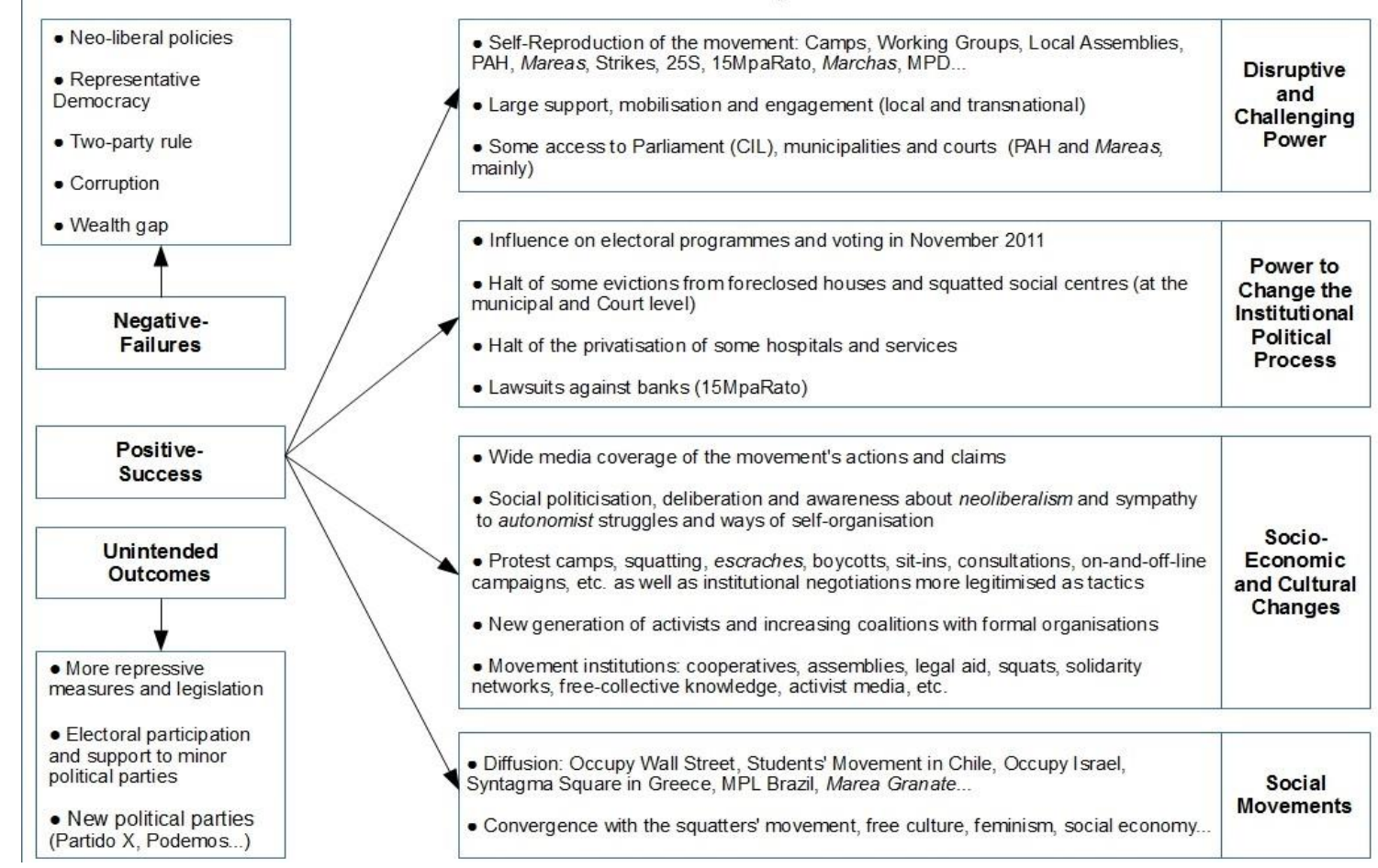

\section{CONCLUSIONS}

The notions of social movements' success and failure are quite controversial so they should not be taken for granted without a critical examination. The assessment of the movement's outcomes depends, above all, on a clear identification of the movement's goals which is not always possible when its social composition is diverse and its evolution may alter the meaning of the goals. Movements can also succeed not necessarily due to their own actions of protest, but also due to others' actions such as allies, third parties, judges or voters. Movements can also produce effects that are not related to their goals or even contradict them.

Besides, for us movement's impacts are evaluated according to the movement's capacity to disrupt the social order and challenge the powerholders. They include the selfreproduction of the movement, its legitimation, recognition, access to state institutions, bargaining power and non-institutional effects in the economic, cultural and social spheres. Some of these aspects were neglected or overvalued in other approaches. Our theoretical approach is also based on the assumption that the movement's goals are interpreted according to the significant contexts from which they emerge. Goals may be single or multiple, more or less formalised. They need to be expressed and defined by participants in the movement but, more importantly, they are selected among the options offered by specific social and political circumstances. Thus, we have distinguished the waves of contention, the political 
opportunity/constraint structures and specific systemic contradictions as the major contexts where the movement's goals can be determined to be meaningful.

Our third standpoint is that every distinction of impacts does not necessarily refer to the causes and grievances that originated in the movement, so that it deserves a particular analysis in relation to its variable socio-political significance in terms of the conflictive power relationships in which the movement is embedded. Instead of searching for their causal relationship with the organisation, the repertoire of protest or the genealogy of the movement, we consider that movements' outcomes are usually their by-products -not merely or even the satisfaction of their claims.

A prevailing opinion about the $15 \mathrm{M}$ is that it hardly affected the institutional arena of politics and it achieved no more than some changes in the political culture. The movement would have failed although, at least, it was able to "rekindle hope". This approach has two problems: a) it tends to omit the relevance of the institutional impacts produced by the $15 \mathrm{M}$; b) it restricts the notion of 'political culture' to a broad politicisation of large numbers of the population.

We propose an alternative explanation. First, we argue that the $15 \mathrm{M}$ was constituted by multiple groups, campaigns and forms of protest. Therefore, the goals of the movement were also multiple and sometimes blurred or too broad. A loose identity, however, gave birth to a plentiful number of goals and also to the desire for profound social change. We have framed them according to three categories: explicit, diffuse and specific organisations' claims. By reviewing the contexts in which they emerged and became meaningful we can confirm the radical character of the aspirations and potentials of the $15 \mathrm{M}$ in opposition to the immediate effects of the economic crisis starting in 2008 and, after all, as a movement against the continuing process of de-democratisation which the austerity policies implied.

Secondly, in spite of the radical institutional reforms called for by the $15 \mathrm{M}$ activists, their initial rejection of establishing alliances with political parties and the labour unions, in addition to the tight cohesion of the dominant elites, prevented the $15 \mathrm{M}$ from having direct access to the state. However, we have identified three significant impacts in this regard: a) some specific organisations and campaigns (PAH, 15MpaRato, Marea Blanca, Montamarta, etc.) achieved substantial victories as members of the $15 \mathrm{M}$ or in close association with it; $b$ ) other groups (Comisión Legal Sol, Oficina Precaria, TCJ, Graba Tu Pleno, etc.) also focused on the institutional sphere and remained active over the years without reaching any deep change; c) there was a continuing broadening of networks, alliances and ties with unions and more formal organisations (for example, in the wake of general strikes and in the Marches for Dignity); d) the new political parties (Partido X and Podemos) and electoral platforms were nurtured by activists and demands from the $15 \mathrm{M}$, and were able to undermine the dominant two-party system.

The $15 \mathrm{M}$ was very successful in its self-reproduction over the years without being subject to formal and bureaucratic organisations. Most of the $15 \mathrm{M}$ groups and initiatives that catalysed remained autonomous. They employed a hybrid and transversal discourse instead of repeating leftist clichés in order to keep mobilising large portions of the working and middle classes. This continuous capacity of mobilisation and proliferation, in both autonomous and institutional grounds, was the main source of the challenge to the status quo -which showed symptoms of collapse at the same time that the $15 \mathrm{M}$ experienced a certain decline and replacement by electoral initiatives in 2014, three years later.

Indeed, the $15 \mathrm{M}$ was also very successful in terms of the political culture that it created. The politicisation of many public and private affairs appealed to a new generation of 
activists and gained more social support than former similar autonomous and radical movements. However, it would be a very poor evaluation to limit the political culture to a shift in the hegemonic opinions about politics. Above all, the non-institutional sphere of politics was enhanced and widened. This was based on current and advanced exercises of deliberation and participation that reached thousands of citizens for the first time ever. Furthermore, civil disobedience to unjust laws and to economic injustice was also more legitimised than ever before. In addition, manifold self-managed experiences were developed in the cultural, economic and social spheres. A myriad of co-operatives, squats and solidarity networks burst out although it is not easy to trace them in very accurate terms given their usually informal nature. These all were consistent achievements with the radical democratic aspirations of the $15 \mathrm{M}$ but they were not in direct correspondence with its utmost goals of addressing the elites and policies responsible for the crisis.

According to our discourse analysis and observations, the PAH and its campaign against housing evictions was seen by activists and external observers as the best representative of the positive outcomes of the $15 \mathrm{M}$. Unlike most of the $15 \mathrm{M}$ groups, the PAH is a formal organisation. It was able to host an inter-class composition and its repertoire of protest combined radical actions such as blockading the houses of the people evicted by the police and the squatting of buildings, and various institutional initiatives of negotiations and lawsuits at different political instances (municipal, regional, central and European). Among other few hybrid and successful organisations, the "white tide" (Marea Blanca) striving against the privatisation of the public health system followed a similar path and also achieved some victories in Madrid and Catalonia as a result. In this and other struggles under the same umbrella of the $15 \mathrm{M}$, not only was civil disobedience praised and widely legitimised by society at large, compared to previous years, but police repression was also more criticised than ever.

\section{REFERENCES}

Abellán, J. (2015). De la red a la calle: el proceso de movilización previo a las manifestaciones del 15 de mayo. ACME (forthcoming).

Abellán, J. (2014). Ciudad, crisis y desobediencia: una aproximación a las luchas por la vivienda en Madrid. En Hidalgo, R. and Janoschka, M. (Eds.) La ciudad neoliberal. Gentrificación y exclusión en Santiago de Chile, Buenos Aires, Ciudad de México y Madrid. Santiago de Chile. Pontificia Universidad Católica de Chile, 257-274.

Adell, R. (2011). "La movilización de los indignados del 15-M. Aportaciones desde la sociología de la protesta". Sociedad y Utopía, 38, 141-170.

Aguilar, S. y Fernández, A. (2010). "El movimiento por la vivienda digna en España o el porqué de un fracaso de una protesta con una amplia base social". Revista Internacional de Sociología, 68, 679-704.

Anduiza, E., Martín, I., Mateos, A. (2013). The consequences of the 15-M protests on voting choice in the 2011 Spanish general elections. EPSA Conference, Barcelona. https://www.academia.edu/3708174/The_electoral_consequences_of_the_15M_protests (Consultado marzo 28, 2014).

Bonet, J. (2015). Movimiento 15-M: la fuerza politizadora del anonimato. ACME (forthcoming).

Estudios de la Paz y el Conflicto, Revista Latinoamericana, IUDPAS-UNAH, Volumen 1, Número 1, enero-junio 2020, pp. 13-38. DOI: $10.5377 /$ rlpc.v1i1.9514 
Burstein, P; Einwohner, R; Hollander, J. (1995). The success of political movements: a bargaining perspective. En Jenkins, C., y Klandermans, B. (Eds.) Politics of social protest: comparative perspectives on state $s$ and social movements. Minneapolis: University of Minnesota Press, 275-295.

Cabezas, A. (2011). "Asamblea Popular del 15M en Plaza Dalí: trabajamos en la Plaza de El Corte Inglés, trabajamos en los intersticios". Teknokultura. Revista de Cultura Digital y Movimientos Sociales 8 (2), 193-205.

Campo, S. (2012). Simpatía y participación en el 15M. En Taibo, C. (Ed.) ¡Espabilemos! Argumentos desde el 15-M. Madrid: Catarata.

Castells, M. (1983). The city and the grassroots. A cross-cultural theory of urban social movements. Berkeley: University of California Press.

Castells, M. (2012). Networks of Outrage and Hope. Social Movements in the Internet Age. Cambridge: Polity.

Colau, A. y Alemany, A. (2012). Vidas hipotecadas. De la burbuja inmobiliaria al derecho a la vivienda. Barcelona: Angle.

Corsín, A. y Estalella, A. (2013). "The atmospheric person. Value, experiment, and "making neighbors" in Madrid's popular assemblies". HAU: Journal of Ethnographic Theory, 3 (2), 119-139.

Cruells, M. y Ruiz, S. (2014). Political Intersectionality within the Spanish Indignados Social Movement. En L., M. Woehrle (Ed.) Intersectionality and Social Change. Research in Social Movements, Conflicts and Change, Volume 37, 3-25.

Díaz-Cortés, F. y Ubasart-González, G. (2012). 15-M: "Trajectòries mobilitzadores i especificitats territorials. El cas català". Interface, 4 (1), 235-250.

Díaz-Foncea, M. y Marcuello, C. (2014). "Spatial patterns in new firm formation: are cooperatives different? Small Business Economics". An Entrepreneurship Journal 44, 171-187.

Espinoza, M. (2013). "Politics of Indignation: Radical Democracy and Class Struggle beyond Postmodernity". Rethinking Marxism: A Journal of Economics, Culture \& Society, 25:2, 228-241.

Fernández-Savater, A. (2013a). Ver lo invisible: sobre unicornios y 15-M. Eldiario.es $10 / 5 / 2013$ (http://www.eldiario.es/interferencias/Ver-invisibleunicornios_6_130946909.html) (Consultado 3 March 23, 2014)

Flesher, C. (2011). "The Madrid Bombings and Popular Protest". Contemporary Social Sciences, 6 (3), 289-307.

Flesher, C. (2014). Social movements and globalization. How protests, occupations and uprisings are changing the world. New York: Palgrave Macmillan.

Flesher, C. (2015). "Debunking Spontaneity: Spain's 15-M/Indignados as Autonomous Movement". Social Movement Studies, 14, 2, 142-163.

Fuchs, C. (2006). "The Self-Organization of Social Movements". Systemic Practice and Action Research, 19 (1), 101- 137.

Gamsom, W. (1975, 1990). The Strategy of Social Movements. Belmont: Wadsworth. Giugni, M. (1998). "Was it Worth the Effort? The Outcomes and Consequences of Social Movements". Annual review of Sociology, 24, 371-393.

Goodwin, J. y Jasper, J. (Eds.) (2004). Rethinking social movements. Structure, meaning, and emotion. Lanhan, Maryland: Rowman \& Littlefield.

Estudios de la Paz y el Conflicto, Revista Latinoamericana, IUDPAS-UNAH, Volumen 1, Número 1, enero-junio 2020, pp. 13-38. DOI: $10.5377 /$ rlpc.v1i1.9514 
Holloway, J. (2002). Change the world without taking power. The meaning of revolution today. London: Pluto (http://libcom.org/library/change-world-without-taking-powerjohn-holloway).

Koopmans, R. (2004). Protest in time and space: the evolution of waves of contention. En Snow, D., Soule, S., Kriesi, H. (Eds.) The Blackwell Companion to Social Movements. Oxford: Blackwell, 19-46.

Kriesi, H., Koopmans, R., Duyvendak, J., Giugni, M. (1995). New Social Movements in Western Europe. A comparative analysis. London: University College London.

Kriesi, H. (2004). Political context and opportunity. En Snow, D. Soule, S., Kriesi, H. (Eds.) The Blackwell Companion to Social Movements. Oxford: Blackwell, 67-90.

López, I. y Rodríguez, E. (2011). "The Spanish Model”. New Left Review, 69, 1-15. Martínez, M. y García, A. (2015). The Occupation of Squares and the Squatting of Buildings: Lessons from the Convergence of Two Social Movements. En Tejerina, B. y Perugorría, I. (Eds.) From Social to Political. New Forms of Mobilization and Democratization. Ashgate (in press).

Martínez, M. (2014). "How do squatters deal with the state? Legalization and anomalous institutionalization in Madrid". International Journal of Urban and Regional Research, 38 (2), 646-674.

McAdam, D. (1994). Cultura y movimientos sociales. En Laraña, E. y Gusfield, J. (Eds.) Los nuevos movimientos sociales. De la ideología a la identidad. Madrid: CIS, 43-67.

McAdam, D. (1996). Political opportunities: conceptual origins, current problems, future directions. En McAdam, D., McCarthy, JD., Zald, M. (Eds.) Comparative Perspectives on Social Movements. Cambridge: Cambridge University Press, 23- 40.

Meyer, D. y Whittier, N. (1994). "Social movement spillover". Social problems, 41 (2), 277 298.

Meyer, D. (2004). "Protest and Political Opportunities". Annual Review of Sociology, $30,125-45$.

MOC (2002) En legítima desobediencia. Tres décadas de objeción, insumisión y antimilitarismo. Madrid: Traficantes de Sueños.

Morell, M. (2012). "The free culture and 15M movements in Spain: Composition, social networks and synergies". Social Movement Studies, 11 (3-4), 386-392.

Moreno, J. (2013). Democracia, movimientos sociales y participación popular. Lógicas democráticas y lógicas de distinción en las asambleas del 15M. En Escalera, J. y Coca, A. (Eds.) Movimientos sociales y participación en Andalucía. Sevilla: Aconcagua, 263-301. Neidhart, F.; Rucht, D. (1991). The analysis of social movements: the state of the art and some perspectives for further research. En Dieter Rucht (Ed.) Research on social movements: the state of the art in Western Europe and the USA. Boulder: Westview.

Nez, H. (2012). Among Militants and Deliberative Laboratories: The Indignados. En Tejerina, B. y Perugorría, I. (Eds.) From Social to Political. New Forms of Mobilization and Democratization. Bilbao: UPV, 123-138.

OM (Observatorio Metropolitano) (2011). People of Europe Rise up! Crisis y revolución en Europa. Madrid: Traficantes de Sueños.

Pastor, J. (2011). "E1 Movimiento 15-M. Un nuevo actor sociopolítico frente a la "dictadura de los mercados"”. Sociedad y Utopía, 38, 109-124.

Piven, F. y Cloward, R. (1979). Poor people's movements. Why they succeed, how they fail. New York: Vintage.

Estudios de la Paz y el Conflicto, Revista Latinoamericana, IUDPAS-UNAH, Volumen 1, Número 1, enero-junio 2020, pp. 13-38. DOI: $10.5377 /$ rlpc.v1i1.9514 
Piven, F. y Cloward, R. (2005). Rule making, rule breaking, and power. En Janoski, T., Alford, R., Hicks, A., Schwarts, M. (Eds.) The Handbook of Political Sociology. States, Civil Societies and Globalization. New York: Cambridge University, 33-53.

Rodríguez, E. (2013). Hipótesis Democracia. Quince tesis para la revolución anunciada. Madrid: Traficantes de Sueños.

Romanos, E. (2013). Collective learning processes within social movements. Some insights into the Spanish 15M/Indignados movement. En Flesher C. y Cox, L. (Eds.), Understanding European movements: new social movements, global justice struggles, anti-austerity protest. London: Routledge, 203-219.

Romanos, E. (2014). "Evictions, Petitions and Escraches: Contentious Housing in Austerity Spain.” Social Movement Studies, 13 (2), 296-302.

Romanos, E. y Sádaba, I. (2015). From the Street to Parliament trough the App: digitally enabled political outcomes of the Spanish 15M movement. Paper presented at the ESA RN-25 Midterm Conference, Madrid.

Sala, M. et al. (2014). "Un análisis del comportamiento cíclico de las cooperativas y sociedades laborales españolas y de su relación con la actividad económica". REVESCO, $115,7-29$.

Sánchez, J. (2013). Las 10 mareas del cambio. Barcelona: Roca.

Scott, J. (2012). Two cheers for Anarchism. Princeton: Princeton University Press.

Scholl, C. (2012). Two sides of a barricade. (Dis)order and summit protest in Europe. New York: Suny.

Stobart, L. (2014). Whatever happened to the Indignados? 1: Radical struggle http://leftflank.org/2014/03/17/whatever-happened-indignados-part-1/\#sthash.SUfIaBUZ.dpbs (Consultado 3 March 23, 2014)

Taibo, C. (2011). El 15-M en sesenta preguntas. Madrid: Los libros de la Catarata.

Tarrow, S. (1994). Power in Movement. Cambridge: Cambridge University Press.

Tarrow, S. (2005). The new transnational activism. New York: Cambridge University Press.

Tilly, C. (1999). From interactions to outcomes in social movements. En Giugni, M., McAdam, D., Tilly, C. (Eds.) How movements matter. Minneapolis: University of Minnesota Press, 253-270.

Tilly, C. (2003). "Inequality, democratization, and de-democratization". Sociological Theory, 21 (1), 37-43.

Toret, J. (Ed.) (2013). Tecnopolítica: la potencia de las multitudes conectadas. El sistema red 15M, un nuevo paradigma de la política distribuida. Barcelona: UOC.

Viejo, R. (2007). "Pensar en la política del movimiento: ideas políticas y movilizaciones sociales en la Era Global”. Àgora, 17, 13-40.

Whittier, N. (2004). The consequences of social movements for each other. En Snow, D., Soule, S., Kriesi, H. (Eds.) The Blackwell Companion to Social Movements. Oxford: Blackwell, 531-551.

\section{Media sources and documents}

15m.cc. (2015). 15M: «Excelente. Revulsivo. Importante» http://wiki.15m.cc/wiki/15M:_\%C2\%ABExcelente._Revulsivo._Importante\%C2\%BB (Consultado abril 20, 2015)

15MpaRato. (2014). http://15mparato.wordpress.com/ (Consultado marzo 31, 2014)

Estudios de la Paz y el Conflicto, Revista Latinoamericana, IUDPAS-UNAH, Volumen 1, Número 1, enero-junio 2020, pp. 13-38. DOI: $10.5377 /$ rlpc.v1i1.9514 
15M Escorial. (2012). Taller sobre desobediencia civil y noviolencia. http://asambleasanlorenzo-escorial.tomalosbarrios.net/?p=3972 (Consultado abril 20, 2015)

15M Horta Albufera. (2011). Taller desobediencia civil pacífica. https://www.youtube.com/watch?v=cAi3Wesedr4 (Consultado abril 20, 2015)

15M Málaga. (2012). http://malaga.tomalaplaza.net/tag/huelga-general/ (Consultado April 20, 2015)

Alvarez, L. (2014). 22-M: la indignidad de la izquierda. La Razón March 23, 2014. http://www.larazon.es/detalle_normal/noticias/5915675/espana/22-m-violento-asalto-dela-izquierda-radical-a-madrid\#.Ttt1TC20N2QpL45 (Consultado marzo 31, 2014)

Asamblea de Logroño. (2013). Mercados de trueque y Cooperativa Regional Riojana. http://www.asamblealogrono.org/tag/cooperativa-integral/ (Consultado abril 20, 2015)

Autoconsulta.org. (2014). www.autoconsulta.org (Consultado abril 8, 2014)

Amnesty International. (2014). Spain: The rigth to protest under threat. http://amnestyv3.temp.brainlane.com/content/assets/Doc2014/Spain_formatted_24_03_14.pdf (Consultado marzo 12, 2015)

Bookcamping. http://bookcamping.cc/ (Consultado abril 20, 2015)

Calvo, K. (2011). ¿Merecía tanto la pena? Sobre las consecuencias políticas del Movimiento 15-M. Público mayo 6, 2012.

http://www.publico.es/432111/merecia-tanto-la-pena-sobre-las-consecuencias-politicas-delmovimiento-15-m (Consultado marzo 30, 2014)

Carmen y Carlos. (2015). Manifiesto de la campaña para la absolución de Carmen y Carlos. https://carloscarmenabsolucion.wordpress.com/manifiesto-de-la-campana-para-laabsolucion-de-carlos-y-carmen/ (Consultado abril 20, 2015)

Colau, A. and Alemany, A. (2014). La PAH ya ha ganado. Eldiario.es February 21, 2014 http://www.eldiario.es/contrapoder/PAH-ganado_6_231386862.html (Consultado abril 4, 2014)

Comisión Análisis. (2011). Taller sobre desobediencia civil. Compilación de intervenciones. https://n-1.cc/file/download/1292408 (Consultado abril 20, 2015)

Comisión Legal Sol. http://legal15m.wordpress.com/comunicados/ (Consultado abril 3, 2014)

Corrala de Vecinas la Utopía. (2015). http://corralautopia.blogspot.hk/ (Consultado abril20, 2015)

Delclós, C. (2013). Victims no longer: Spain's anti-eviction movement. ROAR Magazine December 20, 2013. http://roarmag.org/2013/12/plataforma-afectados-hipoteca-spain/ (Consultado marzo 31, 2014)

Derechos civiles 15M Zaragoza. (2014). Taller desobediencia civil. http://derechoscivileszgz.blogspot.hk/2014/01/taller-desobediencia-civil-poner-en.html (Consultado abril 20, 2015)

Diso Press. (2015). Fuerzas diversas se juntan en las calles de Madrid para expresar su rechazo al TTIP. http://disopress.com/gallery.php?mode=all\&id=NDkyMTEzMWU2ZjI5Nzc=\&page=1 (Consultado abril 20, 2015)

DRY Barcelona (Democracia Real Ya). (2012). 12M Movilización global - Día de acciones 15M. http://barcelona.democraciarealya.es/12 m15m/ (Consultado mayo 12, 2012)

DRY Madrid (Democracia Real Ya). (2014). Commemoration of 30,000 followers. Facebook (Consultado marzo 18, 2014)

Economía Sol. http://madrid.tomalaplaza.net/tag/economia-sol/ (Consultado abril 20, 2015)

Estudios de la Paz y el Conflicto, Revista Latinoamericana, IUDPAS-UNAH, Volumen 1, Número 1, enero-junio 2020, pp. 13-38. DOI: $10.5377 /$ rlpc.v1i1.9514 
Elola, J. (2012). La silenciosa expansión del 15-M. El País mayo 5, 2012 http://politica.elpais.com/politica/2012/05/05/actualidad/1336234920_810740.html (Consultado marzo 31, 2014)

Fernández-Savater, A. (2013b). El papel del movimiento 15-M en los orígenes de Occupy Wall Street. http://www.eldiario.es/interferencias/15-MOccupy_Wall_Street_6_132346774.html (Consultado abril 20, 2015)

Gálvez, M. (2011). El programa electoral de la indignación. http://www.unitedexplanations.org/2011/11/18/la-influencia-del-15m-en-los-programaselectorales/ (Consultado marzo 31, 2014)

Graba Tu Pleno. http://www.grabatupleno.com (Consultado abril 20, 2015)

Grup de Defensa de la Sanitat Pública. (15mBCN-Salut) (2015)

https://defensasanitatpublica.wordpress.com/ (Consultado abril 20, 2015)

Gutiérrez, B. (2014). Theory Thursday: It Is Not a Revolution, It Is a New Networked Renaissance. Occupy Wall Street

(http://occupywallst.org/article/theory-thursday-it-not-revolution-it-new-networked/)

INJUVE (Instituto de la Juventud de España). (2011a). Jóvenes, actitudes sociales y políticas, Movimiento 15M.

http://www.injuve.es/sites/default/files/2012/42/publicaciones/Sondeo\%202011-2a.pdf

(Consultado marzo 31, 2014)

La Huerta del Sol. (2015). Quiénes somos. http://lahuertadelsol.es/quienes-somos/ (Consultado abril 20, 2015)

La Uni en la Calle. http://lacompluenlacalle.blogspot.hk/ (Consultado abril 20, 2015)

Llámalo $\quad Y \quad$ (2013) Resultados Encuesta 15M. https://lamaloy.wordpress.com/2013/05/15/resultados-encuesta-15m/ (Consultado abril 20, 2015)

Madrid 15M. (2012a). Balance del 14N y perspectivas de futuro: hacia la próxima huelga general. http://madrid15m.org/numero-9/ (Consultado abril 20, 2015)

Madrid 15M. (2012b). El 15M y otros movimientos "empujan" a los concejales de Guadarrama a bajarse para este año un $10 \%$ el sueldo bruto. http://madrid15m.org/numero-1/ (Consultado abril 20, 2015)

Madrid 15M. (2012c). La Asamblea de Pinto denuncia a la Alcaldesa por prevaricación. http://madrid15m.org/numero-2/ (Consultado abril 20, 2015)

Madrid 15M. (2014). http://madrid15m.org/ (Consultado marzo 31, 2014)

Ministerio de Empleo. (2015). Datos estadísticos de economía social. http://www.empleo.gob.es/es/sec_Trabajo/autonomos/economiasoc/EconomiaSocial/estadisticas/index.htm (Consultado abril 20, 2015)

Montamarta Espacio Vecinal. (2015). http://evmontamarta.org/ (Consultado abril 20, 2015)

MPD (Movimiento por la Democracia). (2014). Presentation of the Chart for Democracy. https://www.youtube.com/watch?v=wGTCsEWE5Pg (Consultado marzo 14, 2014)

Oficina Precaria. (2015). http://oficinaprecaria.org/ (Consultado abril 20, 2015)

Oliden, I. et al. (2013). Los hijos del 15M ya andan solos. Eldiario.es mayo 12, 2013. http://www.eldiario.es/politica/hijos-andan-solo_0_130887633.html (Consultado marzo $31,2014)$

Partido X. http://partidox.org/ (Consultado marzo 28, 2014)

PAH (Plataforma de Afectados por la Hipoteca). http://afectadosporlahipoteca.com/

SR (Spanish Revolution). (2014). Calls to "Marchas por la Dignidad" (images). Facebook (Consultado marzo 21, 2014)

Estudios de la Paz y el Conflicto, Revista Latinoamericana, IUDPAS-UNAH, Volumen 1, Número 1, enero-junio 2020, pp. 13-38. DOI: $10.5377 /$ rlpc.v1i1.9514 
Stelfox, D. (2013). How the corrala movement is occupying Spain. The Guardian March 4, 2013. http://www.theguardian.com/world/2013/mar/04/corrala-movement-occupyingspain (Consultado abril 8, 2014)

Tribunal Ciudadano de Justicia 15M. (2015). https://tribunalciudadanodejusticia.wordpress.com/ (Consultado abril 20, 2015)

ZNet. (2015). Participatory Economics. https://zcomm.org/category/topic/parecon/ (Consultado abril 20, 2015)

\section{Acronyms}

DRY Democracia Real Ya (True Democracy Now)

JSF Juventud Sin Futuro (Youth Without Future)

MPD Movimiento Por la Democracia (Movement for Democracy)

PAH Plataforma de Afectados por la Hipoteca (Platform of People Affected by Mortgages) SMO Social Movement Organisation

TCJ Tribunal Ciudadano de Justicia (Citizen Tribunal of Justice)

ANOVA Anova-Irmandade Nacionalista (Galician Left-Nationalist party)

CIU Convergencia i Uniò (Catalan Conservative-Nationalist party)

CUP Candidatura d'Unitat Popular (Catalan Left-Nationalist party)

IU Izquierda Unida (Spanish United Left party)

PP Partido Popular (Spanish Conservative party)

PSOE Partido Socialista Obrero Español (Spanish Social-Democrat party)

UPyD Unión Progreso y Democracia (Spanish Conservative party)

\section{REFERENCIA DE LOS AUTORES}

Miguel A. Martínez es Licenciado en Sociología y Ciencias Políticas por la Universidad Complutense de Madrid, y Doctor en Ciencias Políticas y Sociales por la Universidad de Santiago de Compostela, España. Actualmente es Profesor de Sociología Urbana en la Universidad de Uppsala, Suecia. Los principales temas de investigación del autor son los movimientos sociales y el activismo urbano, además de cuestiones de desigualdad urbana, vivienda, espacio público y segregación socio- espacial. Sus principales trabajos pueden encontrarse disponibles en: www.miguelangelmartinez.net / miguel.martinez@ibf.uu.se ORCID 0000-0001-5511-2390

Elena Domingo San Juan es Licenciada en Ciencias Políticas y Sociología por la Universidad Nacional de Educación a Distancia (UNED) y obtuvo el Máster en Pedagogía en la Universidad de Murcia, España. Actualmente es Docente en Enseñanza Secundaria en Dresde (Alemania) en Política, Economía y Español. Sus principales temas de investigación son los movimientos sociales y la pedagogía. dsjelena@googlemail.com

Recibido: 10-10-2019

Aceptado: 31-10-2019

(c) (i) Licencia Creative Commons Reconocimiento 4.0 (CC BY 4.0).

Estudios de la Paz y el Conflicto, Revista Latinoamericana, IUDPAS-UNAH, Volumen 1, Número 1, enero-junio 2020, pp. 13-38. DOI: $10.5377 /$ rlpc.v1i1.9514 